\title{
Punk and the city: A history of punk in Bandung
}

\begin{abstract}
Punk in Indonesia has often been described as a spectacular performance of disorder and resistance, a youthful style that posed a disruptive challenge to the authoritarian hierarchy and discipline of the New Order regime. The punk scene in Bandung has developed in the context of what is often referred to as 'post-authoritarian' Indonesia. Punk gives another historical narrative of the development of urban communities, and, while remaining a minority, is highly visible among urban Indonesian youth lifestyles. This article describes the history of punk's growth and development in Bandung, traced through its relationship to space and place, and through the variety of artefacts it produces such as zines, cassettes and posters. This production and consumption is informed by punk's traditional DIY ethos, and forms the basis for transnational cultural and political relationships.
\end{abstract}

\section{INTRODUCTION}

Bandung is the capital of the West Java Province and is located about $140 \mathrm{~km}$ from the country's capital, Jakarta. As Martin-Iverson argues, Bandung's 'historical orientation to global modernity and cosmopolitan culture is an important aspect' of the city's colonial legacy (2014: 534). As a postcolonial city, Bandung must be considered both in terms of local histories of urbanism and as part of larger, global processes (Kusno 2000). Featherstone (1991) views postmodern cities as centres of cultural consumption rather than industrial production, but in the case of Bandung these roles are tightly connected.

\section{KEYWORDS}

punk

youth subculture cultural production DIY

Bandung Indonesia 
Bandung's creative industries contribute to the spatialization of 'symbolic capital', a process that is tied into neo-liberal forms of urban development (Florida 2004; Harvey 2002; Peck 2009).

Indonesia boasts a thriving underground music scene, including various styles of punk, hardcore and metal, as well as their associated subcultural fashions and identities. The Indonesian underground appears as an unstable alliance of youth culture and service industry workers, urban poor, student activists and aspiring intellectuals (Martin-Iverson 2012). Over the previous decades the New Order regime had effectively forced young people out of the political sphere in Indonesia, especially in Bandung. Political movements associated with punk were instrumental in mobilizing resistance to the Soeharto regime and punk shows became sites for both expressing anti-Soeharto sentiment and organizing politically (Dunn 2016). At its most political, the Bandung underground scene targeted the Indonesian state as a local manifestation of global capitalism (Pickles 2001). The underground reveals the limitations of subcultural resistance, and the recuperative powers of neo-liberal capitalism, as underground independence and political opposition has given way to a precarious entrepreneurialism and the pursuit of subcultural capital (Martin-Iverson 2011).

As Martin-Iverson suggests, Bandung 'has become something of a "style capital" for Indonesia, a major centre for many interrelated cultural or creative industries, including fashion, music, visual arts and new media' (2014: 534, referencing Iskandar 2006; Luvaas 2012: 51; Soemardi and Radjawali 2004). The Bandung punk scene is'significantly influenced by the local culture of the city not so much in terms of its Sundanese ethnic identity or its historic role in the nationalist struggle, but rather its role as a centre of modern urban youth culture' (Martin-Iverson 2014: 535). Clarke et al. (1976) argue that post-Second World War youth used subcultural style to make sense of their changing social conditions, but also to win space and challenge the hegemony of a dominant culture that relegated them to a marginal and subordinate position. Subcultures are presented as a symbolic form of working class resistance, a response to and expression of the breakdown of traditional forms of class identity and the rise of new forms of youth culture (Hall and Jefferson 1976). Hebdige's influential book Subculture: The Meaning of Style (1979) blends this analysis with the Marxist tradition through Barthesian semiotics to describe subcultures, and especially punk, as a rupture in the reproduction of cultural hegemony. Punk, through community-building practices, can offer a strategy for contesting'neoliberal hegemony', with punk aesthetics, Do-It-Yourself (DIY) ethics and the politics of disalienation as the main strategies. Punks still articulate 'resistance' to hegemonic order even in the face of commodification, appropriation and domestication. If creative action is to be revolutionary, it must also relate to and act on the larger social structures in which it is embedded. Punk gives another historical narrative of the development of urban communities in Bandung. In an experimental 'history painting' visual record of the city, photography and artefacts build a narrative of movement as part of the aesthetics of the city. Punk is drawn into the identity, history and memory of the city itself.

Examples from across the historical evolution of punk in Bandung reveal a scene that is richly Indonesian, but also global in scope. Besides empowering individuals in playing music, punk ethics have also been the source of inspiration in enhancing the creations of cultural products, events and artefacts that are different from the mainstream; it transforms passive consumers of mass media into agents of cultural production. The scene is sustained by regular 
underground music festivals, by local bands releasing cassette recordings through local independent labels, and by an array of enterprises, ranging from informal street stalls (lapak) to established shop-front outlets (distro) dedicated to underground music and fashion (Martin-Iverson 2011).

This article draws on the 'scene history' of underground punk in Bandung, traced through gig venues, major events, hangout spaces, political communities, music commodities and zines, and weaves it into the history of urban youth culture in the city, reflecting its Indonesian and global context.

\section{THE BANDUNG PUNK CONTEXT}

Post-authoritarian Indonesia can be considered a neo-liberal regime, albeit one which retains many authoritarian and oligarchic characteristics (Robison and Hadiz 2004). The decay of the New Order did see the rise of flexible and fluid consumer identities and lifestyles, although these remain contested (MartinIverson 2012: 383). Underground styles, such as punk, are highly visible yet remain a minority taste among young urban Indonesian lifestyles. The underground can be considered a form of lifestyle politics, using the consumption of music, fashion and other commodities to construct and negotiate new selfreflexive identities (Featherstone 1991; Heryanto 1999). Underground music continues to provide young Indonesians with a set of alternative identities and lifestyles, providing a route to escape from, challenge or at least negotiate the dominant frameworks of nationality, ethnicity and class (Baulch 2007; Pickles 2007; Wallach 2008: 101). Punk as a global phenomenon provides a toolkit of DIY and subcultural resilience, building and maintaining a community dedicated to its own empowerment, symbolizing a political potential through an aesthetic which is accessible to young people in particular.

Punk practices manifest themselves in various contexts at the local level through the paradigm of global punk. It is characterized by heterogeneous markers, giving voice to relationships situated in a specific time and place, resulting in a daily experimental approach in development of a contemporary history of punk, taking into account the sometimes confusing spatial complexity. This reflects a wider tendency in social theory to view culture and identity as the outcome of mutually constitutive processes of globalization and localization (Featherstone 1995; Friedman 1990). There are important spatial dimensions to this value struggle, but it is not reducible to a process of deterritorialization and reterritorialization, much less to a static opposition between the global and the local. Punk scenes are locally distinct, despite the 'importance of cultural flows between them' (Martin-Iverson 2014: 539, referencing O'Connor 2004). However, as Martin-Iverson (2014: 539-40) points out:

[...] local scenes such as Bandung are, in significant ways, constituted through such connections. Ma (2002: 141-145) describes the 'translocal spatiality' of underground music as being composed of multiple local-tolocal connections and relationships that contribute to an experience of translocal solidarity, a border-crossing form of sociality based on shared symbolic resources, emotional energies, and spatialised practices of production and performance. In the Bandung scene, this sense of solidarity and collective identity incorporates both an imagined global punk underground and specific, personal connections with people in distant scenes.

Punk continuously experiences production and reproduction processes globally and locally in the margin of contemporary (urban) societies' life. These 
1. Lapak is informally selling and/or trading products, but in this case lapak normally consists of cassettes, CDs, vinyl, zines, t-shirts, patches and other underground merchandise, typically laid out on a mat or blanket. processes happen through the dissemination of ideas about the self, providing social (space), history and polity, signalled through commitment in music, scene and community. These processes are also built by highlighting the process of exploration of peripheral boundaries between personality, collectivity, space and place in sociopolitical relations, which involve a globalizing small world - the world of punk.

The punk scene extends beyond the limits of youth culture in its modes of exchange, distribution of commodities, circulation of people and spread of messages. Punk's subversive message works both within and against the hegemony of the capitalist system and government regime. Punk music, style and values (which were considered as 'noise') challenged the accepted norms and values constructed by the New Order, and after its fall in 1998 this resistance developed into the realms of cultural production and media networks that are relatively autonomous from the corporate culture industry. Punk consistently emphasizes the importance of punk ethics in forms of networking and community-building, as well as modes of self-expression. Even the more obviously economic activities such as lapak, ${ }^{1}$ merchandise tables and mailorder distros, are seen as being important mainly as opportunities for social interaction and information sharing.

As Martin-Iverson argues, Indonesian and especially Bandung punks'from various socio-economic backgrounds regularly engage in self-conscious stylistic and ideological identification with a working class identity - albeit one cast largely in global, modern, and even cosmopolitan terms' (Martin-Iverson 2014: 545). He further notes that ' $[t]$ he development of the Bandung scene involved the strengthening of both global connections and a global orientation, which could be described as a form of cosmopolitanism urbanism' (Martin-Iverson 2014: 543), and that 'Bandung punks explicitly value "unity in diversity", a stance that fits into global punk discourse but which also reflects Indonesian nationalist values and broader Indonesian social norms of tolerance and social harmony' (Martin-Iverson 2014: 542, referencing Wallach 2008: 101). The punk culture which emerged in the 1990s was considered to be a new phenomenon within the scope of youth culture in Indonesia, and one of the centres of this was the city of Bandung (Prasetyo 2012). This cultural activity is deeply embedded in Bandung, and has contributed to its distinctive urban character.

\section{A PUNK SCENE BIRTH HISTORY}

In Bandung, music development (including underground music) must be understood in conjunction with the development of television and print media. The New Order's authoritarianism had long-term impacts on the social, political, economic and cultural aspects of Indonesian life, and media control meant that western music was unlikely to be shown by the state broadcaster Televisi Republik Indonesia (TVRI), and mentions in print media were rare. Aktuil magazine (founded in 1967) was an exception, and the fact that it was based in Bandung was important for the development of music in the city. The magazine became the only print media to provide a variety of information related to music, especially rock music from the West. Later, through this magazine, young people in Indonesia came to know bands like the Sex Pistols, the Clash and the Ramones, as well as the associated fashions. The punk embryo in Indonesia cannot be separated from the evolution of rock music in the 1970s, and indeed, the term 'underground' had been used by Aktuil magazine since the early 1970s to identify bands who played hard music 
with a 'wilder' and more 'extreme' style. The rock music scene in Indonesia began to variegate with the development of private television in 1993. The emergence of MTV provided insight into the global music scene, including punk, because up to that point information could only be obtained from tapes, CDs and vinyl specifically circulated in Indonesia, and this was of limited affordability for many people. In addition, especially in Bandung, people were also getting information through radio, including radio frequencies leaking from Australia. Punk developed rapidly as a musical entity, spawning new fashion trends in Indonesia. This began as a sentimental fandom of particular bands but later became an inspiration and influence in music and in daily life. In addition to being fans of music, young people in Bandung were exposed to the symbols/logos contained in the fashion, such as the anarchist circled-A.

In Bandung at that time, if a new band sought to perform they were usually obliged to audition (a popular process in some big cities such as Bandung). If bands were accepted, this was usually decided by nepotism. The punk community in Bandung wanted to contend this practice of (essentially) begging the event organizer. Punk bands were often rejected in auditions, so they decided to make their own independent events by involving all underground music genres including punk, hardcore, metal, etc. This situation led some of the first punk generation in Bandung to the idea that their city might become the centre of punk music activity, as an alternative to the rock hegemony which was centred in Surabaya.

In 1996, punks in Bandung who previously had been hanging out at PI established Riotic and were sent books about anarchism from a network of friends in other countries in the world. This established punk as not just a music scene, but also a social movement informed by anarchism. The circled-A symbol began as a fashion seen on MTV, but over time, and especially nearing the end of the 1990s, punks studying anarchism formed a social movement group called Front Anti-Fasis (FAF), established in Bandung in 1998, which joined the movement to overthrow the New Order. During Reformasi, the oppositional styles and performances of Indonesian punk contributed to the construction of a new collective identity and a radical movement for social change (Pickles 2001). They came to radical or anarchist politics through their involvement in the underground music scene, and their politics remain closely associated with punk. Reformasi was the highpoint for anarchist-punk in the Indonesian underground, a combination of militant anarchist politics and aggressive punk music that gave voice to newly assertive identities and politics of youth (Pickles 2007). Indonesian anarchist-punk took the ascendant liberalizing tendencies of the Reformasi era to an extreme, emphasizing a radical and disruptive form of individual autonomy against the disciplining powers of the state (Martin-Iverson 2011). Radical activist politics and protest movements have often drawn on the aesthetics of punk and other music-based subcultures to build 'cultures of resistance'. As Dunn (2016) notes, anti-government songs became popular, political tracts (especially in the form of zines) were produced and disseminated, and anarchist-inspired actions were planned. In Bandung, punk became one form of resistance by marginalized communities towards the militarist and fascist New Order regime. Even though the impact of this resistance was arguably insignificant, through their lyrics the punkers developed a critical narrative about civil society. The establishment of FAF marked the dividing line between 'anarki punk' and street punk. The political orientation of FAF was anarchist which distinguished them from the street punks who were primarily concerned with a punk aesthetic, and who, 
due to their intimidating activities in the street, were viewed with disdain by the general public. This street punk image, because of its regular yet intimidating performance in daily public life, became the main popular image of punk.

Early punk activities in the political arena included organizing protests in Bandung in 1996 to criticize the regime, including the first organized rally of punks in Bandung. After watching a music event in GOR Saparua, there were plans to 'create anarchy' in Bandung at a demonstration on New Year's Eve 1995. Initially the demonstration was planned to fight with the police, but events surpassed this ambition. The rally became a march from Dago to Alun-alun $(10 \mathrm{~km})$ with about 150 people from FAF involved in the rally. Along the way, advertisements such as baligo and billboards were destroyed because they were seen as symbols of capitalism. They also ruined some government officials' cars, as they viewed the government as a corrupt and fascist regime. A total of 48 people were arrested and the rally became national news. As a result of this rally, ahead of New Year's Eve 1996 the police announced that they would shoot on sight any anak-anak punk who conducted an anarchistic rally to damage public facilities and disturb public order.

The establishment of FAF drew upon the social and political crisis and the aspiration to overthrow the Soeharto regime. FAF later became associated with Partai Rakyat Demokratik (PRD) because of its militancy and antiSoeharto vision. FAF took part in various demonstrations, voicing anti-fascist and anarchist political messages as part of its public awareness efforts to immediately overthrow the New Order regime (figure 1a). However, due to ideological differences, FAF decided to leave the PRD in 1999.

After 1999, punk was no longer active in organized urban political movements. Punk divided into two groups: one focused on music and lifestyle; the other decided to leave their punk identities and joined with political movement groups to help marginalized communities in urban and rural areas.
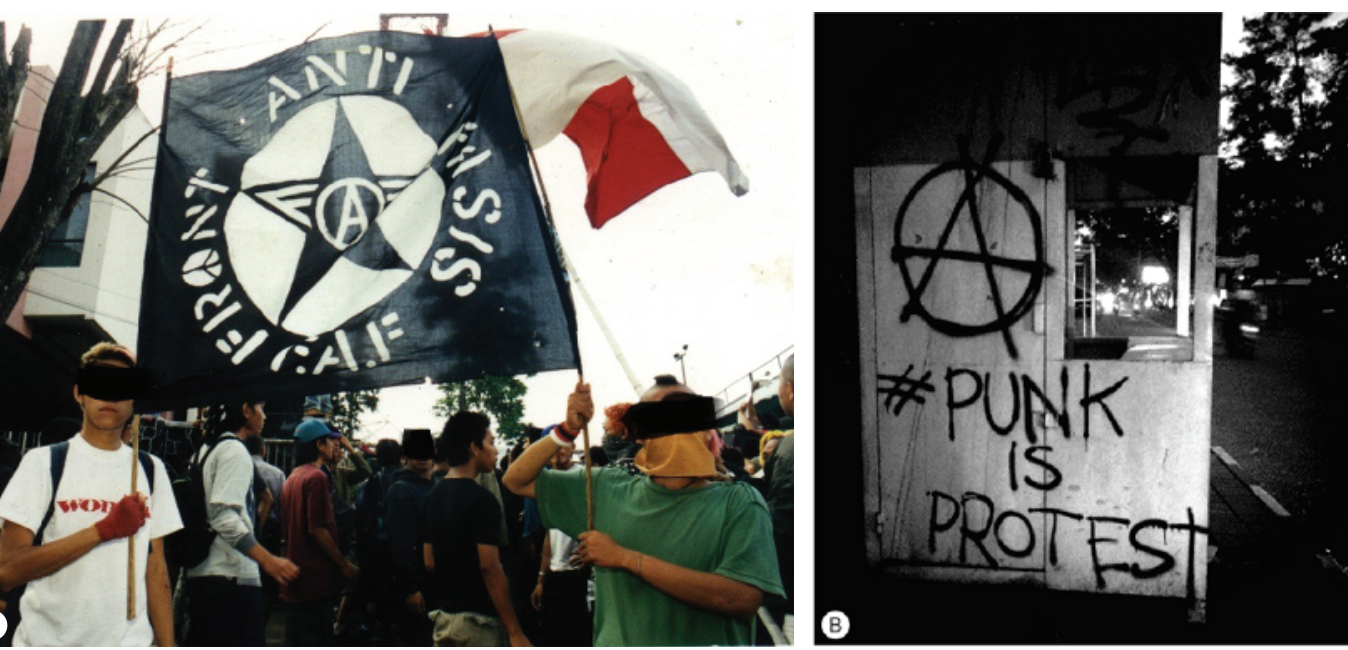

Figure 1: (A) Front Anti Fasist (FAF) Campaign in Bandung - 1998, photo by Anonymous; (B) Graffiti 'Punk is Protest', photo by Frans Ari Prasetyo (C) 2013. 
In the Bandung punk community, this is expressed as a suspicion of 'totalizing' ideologies and managed spectacles of resistance, though it is ometimes developed into a more general scepticism of political organization and strategic thinking. But militancy is still expressed in the Bandung punk scene, especially in public spaces at hangouts, at gigs and when gathered for demonstrations such as May Day.

\section{VENUES AND GIGS}

In the early 1990s, music events in Bandung were dominated by rock (mostly associated with the Log Zhelebour record company), and these were centred around GOR Saparua venue (Figure 2), chosen because of its strategic location in the city centre and cheap rent. The venue attracted many musicians from various genres from the early 1980s onwards, yet events were infrequent. At that time, most music events were held in open fields and the dominant genre was dangdut. ${ }^{2}$ Only when rock music was accepted by the wider public, did the Saparua building become their regular concert place. The building itself is located in front of the central West Java military building and was owned by the city government of Bandung. The Saparua building was formerly known as Gedung Olah Raga (sport centre) hence the 'GOR' abbreviation. In the face of later growth, fragmentation and commercialization of the scene, the Saparua era is now looked back on as something of a golden age of scene unity and underground authenticity (Martin-Iverson 2011).

In 1994 Hullabaloo 1 was held as the first punk 'proto show' in Bandung and was notable as a large-scale event funded without commercial sponsorship (Figure 3A). There were 40 individuals involved as organizers, each donating IDR 50,000 from their own pockets (paid in three intervals), raising an estimated IDR 2 million concert budget. This was obviously an expensive commitment for school-age young people or those without jobs. The IDR

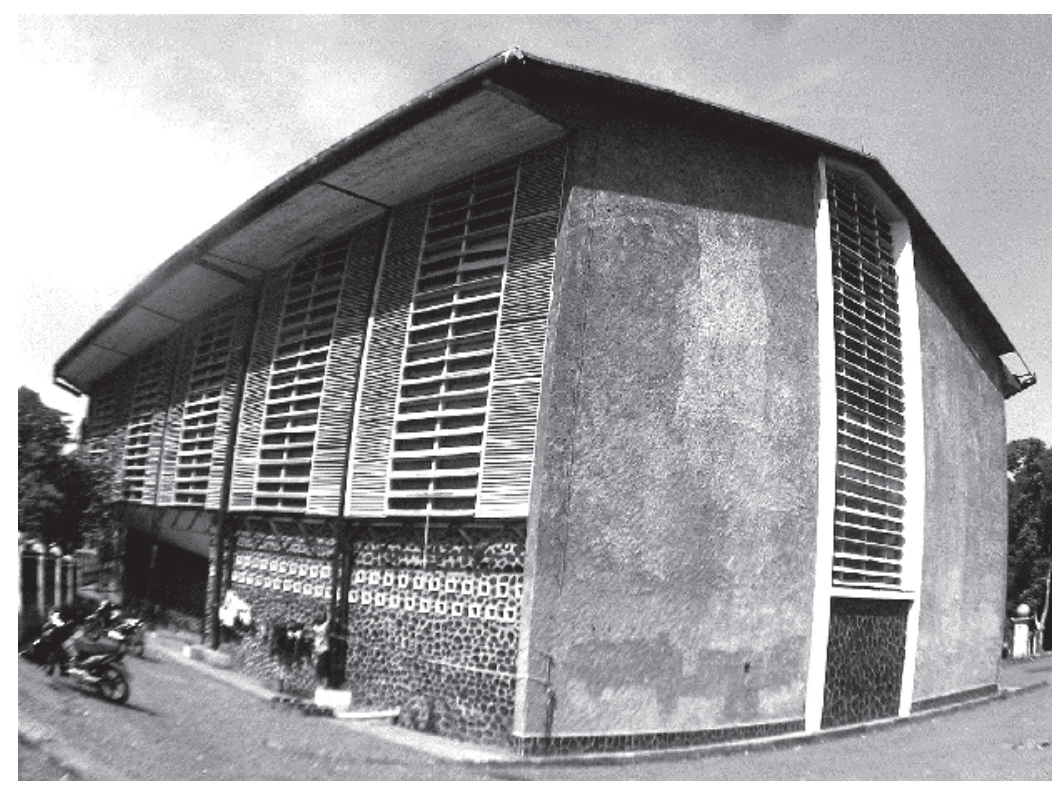

2. Dangdut is understood as a music 'of the people' (rakyat), but was presented in publications such as Aktuil as backward, hickish and unsophisticated (kampungan) (see Weintraub 2006: 441-31).

Figure 2: GOR Saparua. Photo by Frans Ari Prasetyo (C) 2009. 

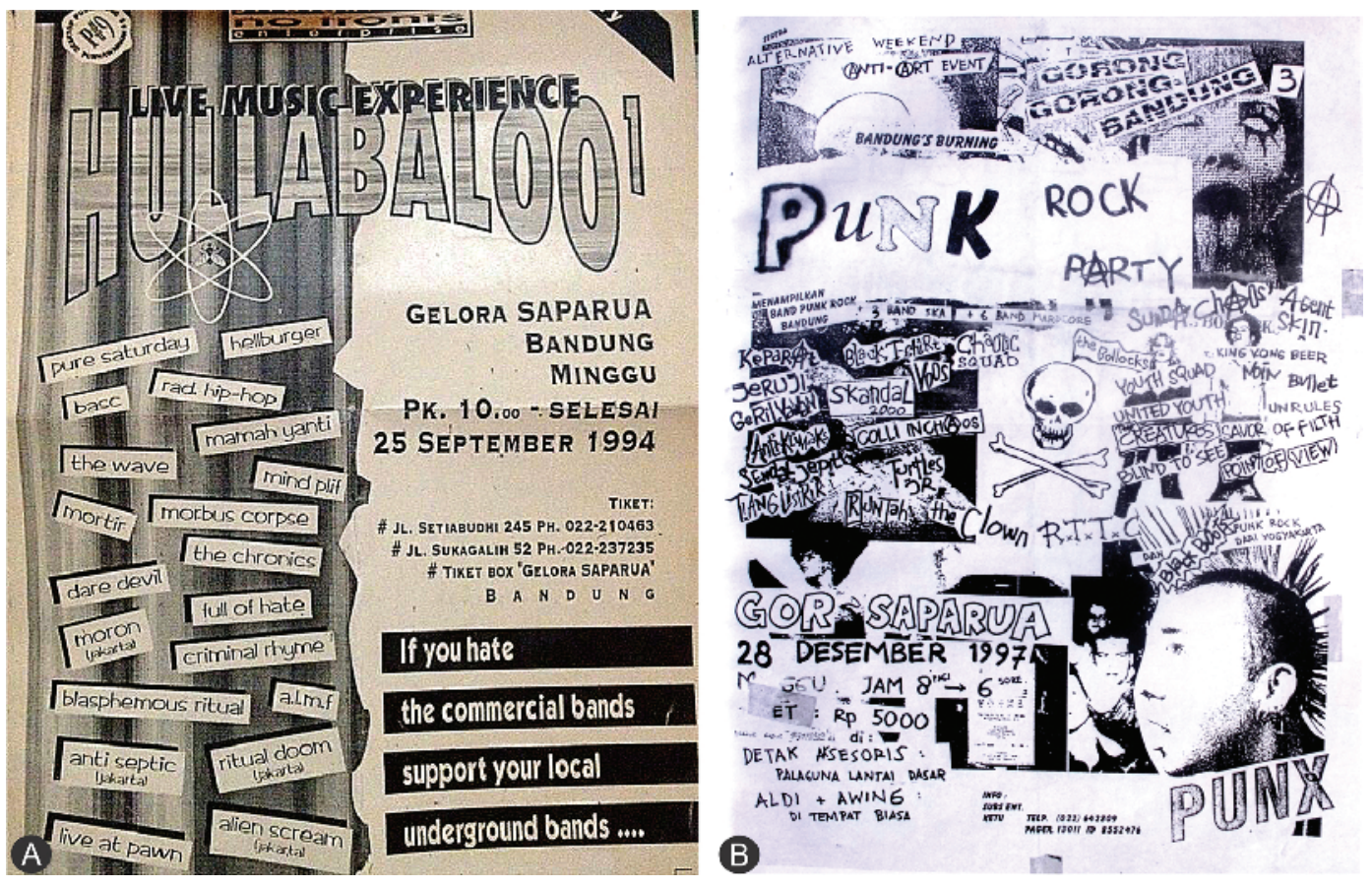

Figure 3: GOR Saparua Gigs (A) Hullabaloo 1 - 1994; (B) Punk Rock Party - 1997. Collections and owner of this posters by Frans Ari Prasetyo (C) 1994 and 1997.

two million paid for the building hire, sound system and permission from the local officials, as well as the money needed to bribe the police and military for 'security fees'. Hullabaloo 1 was a success, attended by the underground mass from greater Bandung and some smaller cities nearby such as Lembang, Cimahi, Sumedang, Soreang and Majalengka. Having succeeded on the first occasion, the organizers planned to make it a routine annual event. After Hullabaloo 1, punk, metal and hardcore music events started to proliferate in corners of the city, and these events became a kind of exposure for the involved bands to be able to perform in the next Hullabaloo. Hullabaloo 2 was held in May 1995, and the organizers had learned from the first event - this time there was no security (ordinarily supplied by the police or local paramilitaries). In addition, the audiences were becoming familiar with various dance styles associated with punk music, such as moshing, pogoing and headbanging, though these kinds of dances sometimes triggered fighting. Hullabaloo 2 inspired music communities in Bandung to hold other music events, such as Bandung Underground and Bandung Berisik 1, which mostly featured metal bands. Having seen the success of Hullabaloo 1 and 2, Bandung Berisik 1 to 4 (1995-2002) were held in GOR Saparua. The event was staged again in 2003, but not again until 2011 (and then annually until 2014) but is no longer held in GOR Saparua, and now takes place in an open field owned by the military. Until the fourth incarnation of the event in 2003, Bandung Berisik remained collectively managed by the community, but, since 2011, Bandung Berisik has been co-opted through a sponsorship scheme. In addition to Bandung Berisik there have been other events, such as Bandung 
Underground (1996), Gorong-Gorong 1 and 2 (1997) and Punk Rock Party 1 and 2 (1997) (Figure 3B), all of which used GOR Saparua as a venue.

Between 1997 and 1999 there was a boom in the popularity of ska music, with many events held in Saparua, especially the regular 'Sunday Ska' event. In addition, in 2001, there was a music event named Dozen of Terror, initiated by Generasi Muda Radio - GMR Underground Bandung Radio. Bands who performed at that event were those who were most often requested on the radio programmes Indonesia 9 and Request Line, including Barong, Logam, Virus, Balcony, Koil, Forgotten, Dajjal, Geboren, Crusade, Burgerkill, Jeruji and Turtles Jr. The event attracted about 5000-7000 people to Saparua.

After this success, no other event has attracted such a large audience. After 2001, Saparua was no longer used due to the difficulties of getting security permits and the poor condition of the building itself. Another factor was the number of weekly events held in Saparua, which by now had reached saturation point. In the period of 2000-01 the underground scene in Bandung started to become fragmented between various music genres and sub-genres. In 2005, for the last time, the Saparua building was used because of the nostalgic and romantic sense of this place (Figure 4).

As Saparua was no longer used for music events, the underground communities needed alternative spaces in Bandung that could accommodate more than 5000 people and were ready to hold underground events. Such spaces were rare, and negative stigma around the underground community made it difficult to find any venues for events. The eventual choice was the Dago Tea House building owned by the West Javanese provincial government. The building manager allowed the underground communities to use the building for the music event because the rent price was expensive and the communities guaranteed that there would be no 'chaos'. In addition, the manger recognized that the building was intended to be used to facilitate any

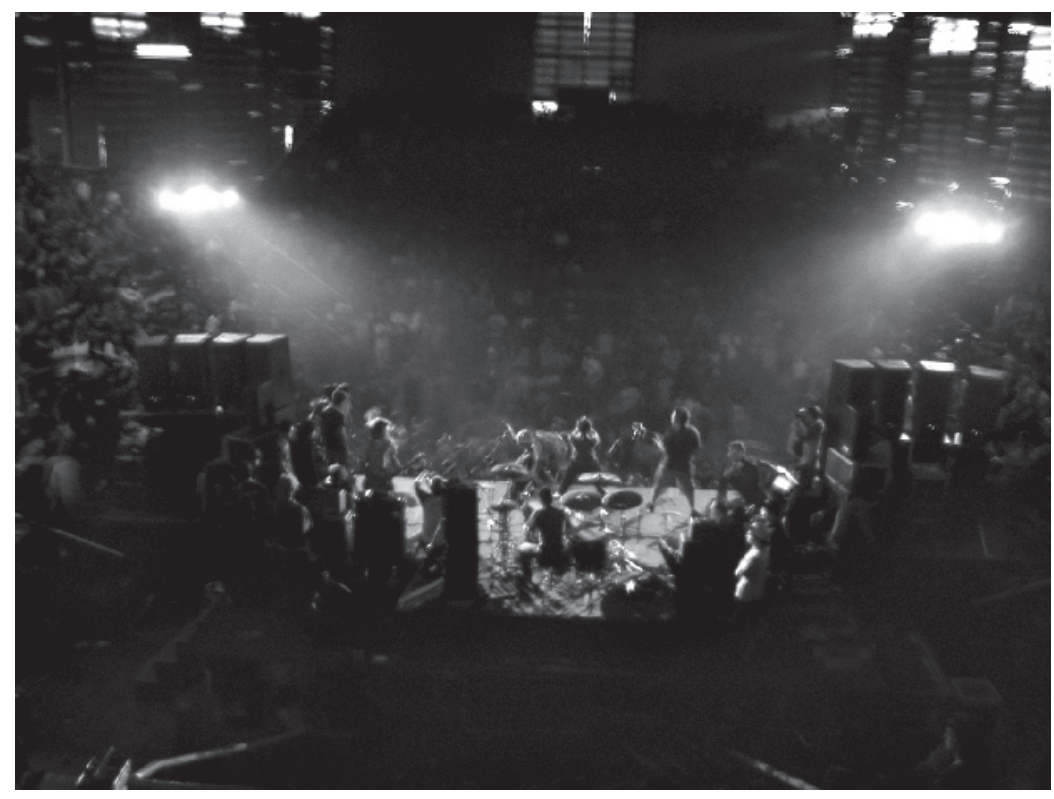

Figure 4: Event in GOR Saparua. Photo by Frans Ari Prasetyo (C) 2005. 
3. The ABRI (Angkatan Bersenjata Rebuplik Indonesia) was The Indonesian Armed Forces (Military and Police) and had a 'dual function'; playing a central role in 'contributing to the nation's development', first as a defense and security force, and second, as a sociopolitical force. Since 1999 after Reformasi, ABRI was divided into TNI (Tentara Nasional Indonesia - the military) and POLRI (Kepolisian Republik Indonesia - the police). art and music activities, including underground music. The first music event at the Dago Tea House building was One Blood in 2005, attended by a large audience of 5000 to 10,000 people. However, since 2007 the manager has not allowed underground communities to use the building for events, due to many events ending up in 'chaos' and resulting in damage to some parts of the building.

Outdoor spaces provided another venue option, however many outdoor or open field spaces in Bandung are owned by military and police institutions many underground music events in Bandung have, in fact, been held in military/police-owned fields. Some punk communities refuse to be involved in any events held in military areas, identifying the military/police as a remnant of the fascist regime which ought to be resisted, an aspiration that features in numerous song lyrics such as 'Cabut Dwifungsi $\mathrm{ABRI}^{3}$ by Kontaminasi Kapitalis. The majority of these bands later joined the PI punk collective, marking the beginning of fragmentation in the Bandung underground scene. The PI collective were also opposed to corporate sponsorship, but another fragmenting group, known as Ujung Berung Rebel, organized (mostly metal) events such as Bandung Berisik, Bandung Death Fest 6 (2012) and Bandung Dooms Day (2015) with funding from various sponsors.

In 2003, the PI collective organized the first punk event of the postSaparua era in Buqiet Café, using the name of Koletif Bintang Hitam or Klub Racun (Figure 6). Buqiet Café, which is located outside the city, was chosen because of the relatively cheap rental price. Between 2003 and 2006 other punk events were also held in places such as IF Venue, in the form of small and exclusive events. IF Venue, an alternative space located in Bandung city centre, was established in May 2004 with the tagline 'Music, Art and Literacy'. IF Venue regularly hosted live underground music, including punk, alongside art exhibitions, political discussions, a variety of workshops and residency programmes, and alternative education related to music, art and literacy. Punkers who had worked with IF Venue created a fundraising scheme named SpaceAid, with some famous punk bands from Jakarta and Bandung performing at SpaceAid benefit events (as well as two international bands, 7Crowns [UK] and Purk [Germany]). The latter event was attended by more than 1000 people, even though the capacity of IF Venue was only 150 (Figure 6). Consequently, many people gathered along Moch Ramdan street, almost blocking the traffic, and the event was subsequently stopped by the police. The owner of the house was compelled to close the venue for one week, and the lease on the space was then cancelled, even though IF Venue had money to pay the rent. After the closure of IF Venue, it was noted that the Bandung police became more aggressive towards the punkers' activities. Because of this, some punk events started being organized secretively and the dissemination of information about punk events became more exclusive, resulting in an increased perception of elitism in the Bandung punk scene.

In the post-Saparua era, another alternative for punk music events is to rent music studios. Studio shows are intimate jam sessions held in the close quarters of a practice studio which originated out of necessity - a lack of venues and scarce resources make it difficult to put on a large public show in Bandung without commercial sponsorship. The rent is paid collectively by all bands that perform, in a similar way to Hullabaloo 1, albeit on a smaller scale. Punkers do not need to get permission because the studios themselves already have official permits to operate, and they are also able to avoid immigration checks if an event features an international punk band on tour in Bandung. 

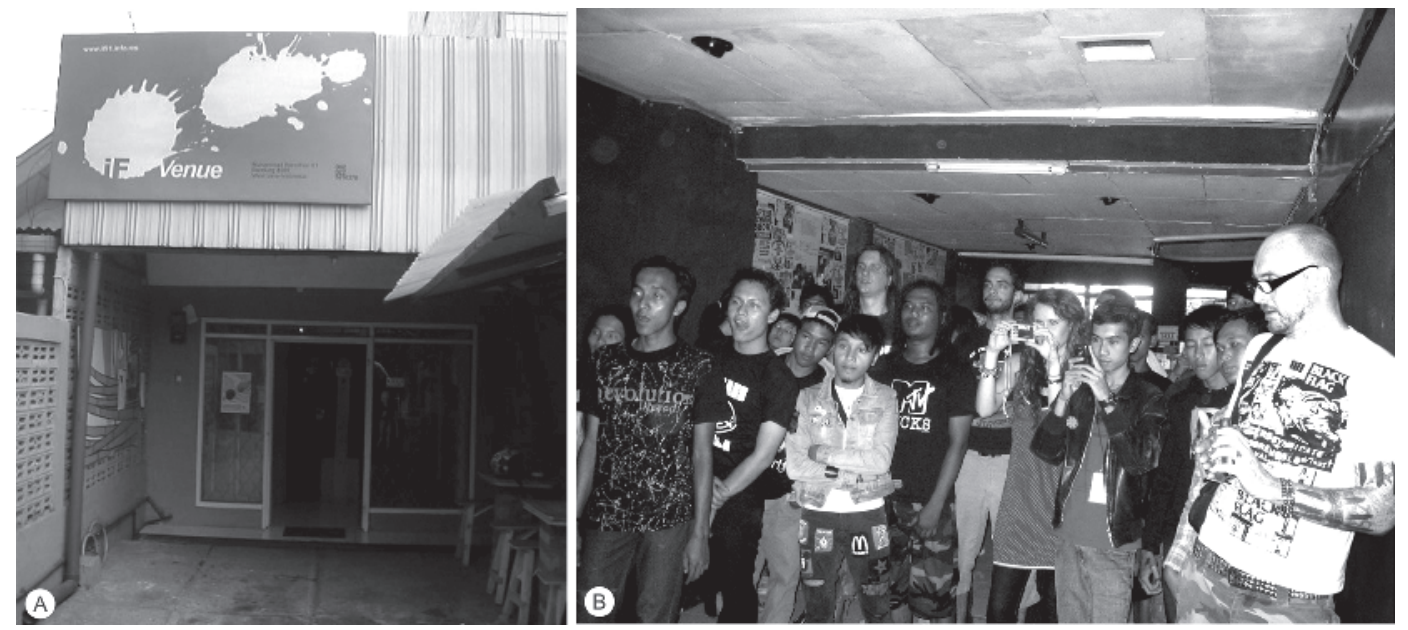

Figure 5: (A) IF Venue; (B) Time Bomb Gigs organized by PI Collective/Klub Racun as a benefit for SpaceAid Project for IF Venue. Photo by Frans Ari Prasetyo (C) 2006.
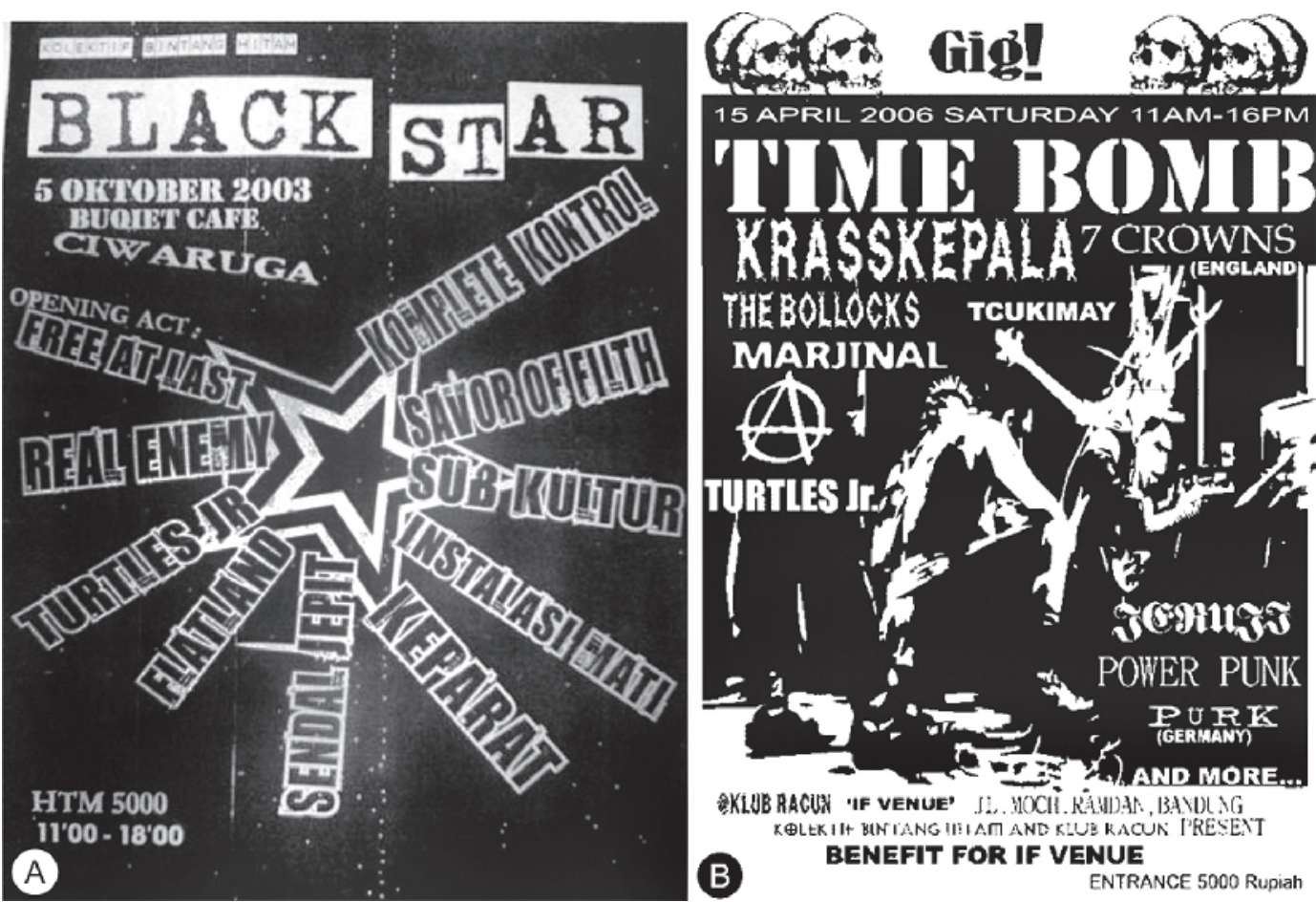

15 APRIL 2006 SATURDAY 11AM-16PM

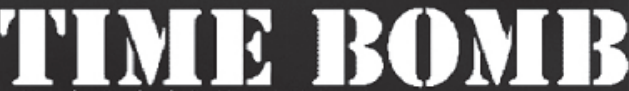

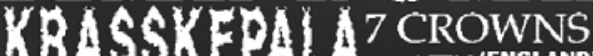

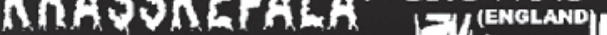
THEBOLLOAKS TCUKIMAY Hy MARJINAL "

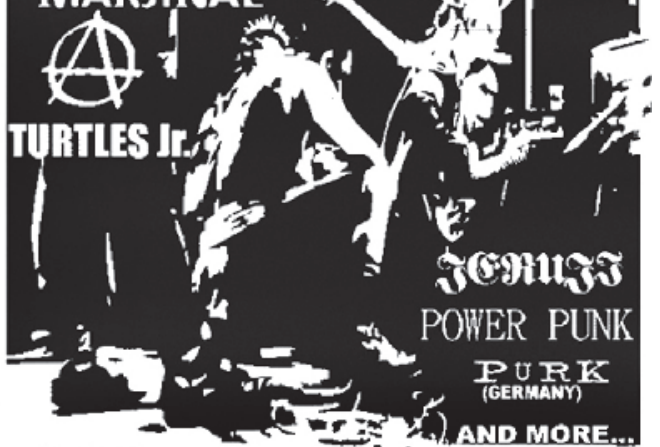

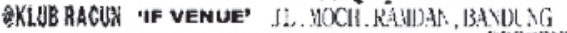
K由LEKII+ BINIANG IIIATI AND KLUE KAOUN I'RESENT BENEFIT FOR IF VENUE

ENTRANCE 5000 Rupiah

Figure 6: Poster event PI Collective/Bintang Hitam Collective/Klub Racun: (A) Buqiet Cafe (2003); and (B) IF Venue (2006). Collections and owner of this posters by Frans Ari Prasetyo () 2003 and 2006.

Overcoming these obstacles, even in a small way, provides a real sense of victory and solidarity (Martin-Iverson 2011). The strategy of using music studios for events, especially punk, was first done by the Balkot Collective in 
2005 at locations including: Studio Jawara in Lengkong Besar street, Grama Studio in Cihampelas street, Elang Studio in Abrahman Saleh street, Great Studio in Antapani Road. Not all music studio owners allowed their studios to be used for the music events, for two reasons: first, to avoid damage to their musical instruments and equipment, because of how the punk bands might use them; second, for security reasons. Studio shows, often termed 'making a collective', have become a more realistic choice after the Asia Africa Cultural Centre tragedy in February 2008 in which eleven people died at an underground event. After that tragedy, it became more difficult to hold punk music events in Bandung and another alternative has been to organize events in smaller cities around Bandung such as Cimahi, Sumedang and Lembang.

The constantly changing methods of organizing punk gigs in Bandung reflects the growth and subsequent fragmentation (and increasing sub-genre specificity) of the scene, but also highlights the institutional and economic pressures faced by punk communities in Bandung.

\section{HANGOUTS, LAPAK AND DISTROS}

Punks' occupation of space in Bandung has extended beyond venues for music events. As Martin-Iverson (2014: 535) notes:

Bandung's punks also claimed more public areas of urban space as their hangout spots (hangout or tempat nongkrong), places in which they gather to talk, drink, smoke, trade, organise, and demonstrate their presence to the wider urban public.

The story of the punk hangouts in Bandung began after Hullabaloo 1 in 1994. After the event, the punkers were looking for a place where they could buy alcohol, and the backyard of Badung Indah Plaza (BIP) mall in Cikapundung (a busy area for newspaper distribution) became the first choice because of the Taurus Shop there that sells alcoholic drink. Many local 'citizen vigilantes' (i.e. paramilitaries) also drank in this area, and the punkers then decided to move to the front of BIP mall during the day; an area that was more convenient and with a shop named Panti Karya (PK) nearby which sold drink at a cheaper price than Taurus, and another gathering spot at the Dago 34 near the Panti Karya shop. Besides simply hanging out, the activities of the PI collective and their presence at BIP mall became a political display to the public about the existence of punk and political choices as part of the youth culture of resistance. The BIP hangout also became their economic base through the creation of Riotic distro. 'PI' originally stood for Pasar Induk (big market), referring to the rear of BIP mall which was crowded like a market with people loading goods, and where the mall workers parked their motorbikes, ate lunch and so on. Later, there was an anecdote that 'PI' refers to Pondok Indah Mall (PI Mall), the most luxurious mall in Jakarta, and that the PI collective wanted to show that they could hang out in their own subverted version at BIP, as a comment on access to 'luxurious places'.

As Martin-Iverson argues (2014: 535), PI's hangout 'is also an enactment of the social opposition between the anak punk (punk kids) on the street and the anak gaul (trendy kids) in the nearby BIP mall'. The subcultural has also come to signify a particular relationship between aesthetics and resistance which remains important in the Bandung scene; many inside and outside of the underground position it as a form of disruptive cultural 'noise', 
unsettling and challenging the established social order (Martin-Iverson 2011). As Martin Iverson writes, ' $[\mathrm{t}$ ] hese punk hangouts in part reflect wider patterns of youthful, masculine sociality in Indonesia' (2014: 535, referencing Baulch 2007; Luvaas 2012; Wallach 2008). Martin-Iverson (2014: 535) further notes that'[i]n Bandung, while some punks still make dramatic incursions into gaul spaces, for the most part they have abandoned such spaces for their own hangout spots - though some punk distros have also begun to move back into the mall'.

Another prominent punk hangout is on the steps of Bandung's City Hall (Balai Kota), where a DIY hardcore collective named 'Balkot' meets. Balkot collective was the first straight edge collective in Bandung (and in Indonesia). Straight edge and DIY are presented as movements to reform the underground from within, seeking to recover and develop authentic punk values against the reduction of punk to a commodified style (see Martin-Iverson's article in this journal). Straight edge can be seen as an adaptation to the conservative moral norms of Indonesia, but it is also an attempt to salvage what they see as the authentic, positive core of punk from the negative excesses of the underground (Martin-Iverson 2011). In addition to its focus on music, Balkot was also associated with skateboarding, as the city hall area itself was a convenient place to do it. Balkot collective changed its name to become Balkot Terror Project in 2005 to preserve their punk ideology.

In addition to being a site of alternative community and sociality, the underground scene is also a site of cultural production (Wallach 2008). The implementation of DIY ethos in the realm of cultural production has also expanded to the production of clothing and merchandise. While DIY production is opposed to the pursuit of profit, it is still concerned with the production of goods and services for sale - otherwise termed, commodities. Commodities can be said to have their own 'social lives', as material objects to which people develop various affective attachments and socially meaningful relationships (Appadurai 1986). Underground commodities are produced and exchanged through underground enterprises and networks. These commodities are distributed through informal street stalls (lapak), merchandise tables at shows, mail-order, hand-to-hand or, increasingly, through established distribution outlets (distros) located in shophouses, commercial districts and shopping malls (Martin-Iverson 2012). 'Distro' is a global punk term for a DIY distributor that has been adopted by the Indonesian underground. Pioneering distros in Bandung were often associated with independent record labels that also opened retail spaces; underground distros such as Harder and Riotic also served as punk hangouts (tempat nongkrong) and activist centres (MartinIverson 2012). As something of a cultural centre in Indonesia, Bandung frequently offers new ideas in the development of music in Indonesia, and the success of these early distros spawned a thriving industry, selling local fashion and music to style-conscious urban youth. The distro phenomenon has since spread to other urban areas in the archipelago, but Bandung remains its centre with hundreds of distros operating in the city at the height of their popularity. Once a model for independent underground production and distribution, Bandung's distros have expanded and professionalized into a substantial industry based on an integrated business model of underground branding and lifestyle fashion. For many underground youth the shift from a musicbased scene to a fashion industry represents a profound loss of underground authenticity, as Martin-Iverson (2011) argues, the rise of the distro industry and the commercialization of the underground pose a significant threat to the 
authenticity, values, and social cohesion of the Bandung underground scene, but Martin-Iverson (2014: 535) also points out that while the 'distro industry is tied to Bandung's position in the national and regional cultural economy [...] the shops themselves remain important venues for underground sociality'. Bandung scenesters are now focused on asserting the authenticity and independence of their own economic enterprises against state restrictions and corporate appropriation. The struggle for creative autonomy has the oppositional logic of a relatively autonomous field of cultural production, and it can also be regarded as an antagonistic class relation arising from the transformation of creativity into capital.

The fast growth of distribution outlets (distros), which are now widely popular all over the country, started in Bandung - the first distro in Indonesia was Riotic, established in Bandung in 1996. The rise of the distro industry supports McRobbie's (1988) emphasis on the role of entrepreneurial activities within subcultures, as opposed to external appropriation. Riotic distro, founded by PI collective members Toro, Behom, Ica, Linggo, Pam, Ketu and Aldi, began as a militant movement related to punk and anarchism, and also served as an independent economic base. However, as punk itself became increasingly commodified and trendy, Riotic became a distro selling CDs, cassettes, posters, $\mathrm{t}$-shirts, and imported accessories and merchandise. The distro became the basis of the economic autonomy of the PI Collective. Riotic started as a small glass case (etalase) which was cheap and movable, and which could be entrusted to the nearby mini-shop owner during the night. (Reverse Studio, founded in 1994 by Richard Mutter, was in some sense a precursor to Riotic, as a music studio which also sold Bandung bands' merchandise.) In addition to having a modest display, Riotic also functioned as an independent record label to facilitate punkers in producing music and distributing the products to public.

Other punk distros were established in Bandung not long after Riotic, such as Harder in Cihampelas (founded by Sarkaz) and Stress Distro in Setiabudi road. The development of distros became faster in the post-New Order period - among the punk distros there was Anonim (1999) founded by Dede, followed by Endles (2004) and IF Venue (2004). Lately, there have been more new distros lacking the ideology and values practiced by the punk distros. These new distros generally only provide independent clothing production, using a local label that is ultimately no different to any other company's clothing. This bourgeois entrepreneurship is understood as being as opposed to the autonomous and non-hierarchical working of punk distros. As Martin-Iverson (2014: 535) notes:

[...] underground distros such as Harder and Riotic played an important role in the development of Bandung's hardcore punk scene in the 1990s and early 2000s, supporting local bands through their associated record labels and serving as key punk hangouts and organising centres.

After a brief change of location away from BIP mall (to Melong Green), Riotic fragmented, and was taken over by Ketu in 1998, employing Aldi as a worker. The Riotic founders and some other punkers thought that Riotic could no longer accommodate their ideas, so established a new political movement named Front Anti-Fasis (discussed above), and maintained a connection with Harder distro. In early 1998, just before Reformasi, Riotic moved again to the Dago Area, Juanda Road No. 181, and the name changed 
to Riotic 181. A collective community emerged named Sadar 181 (Concious 181) which was a proto-straight edge collective feeding into the emergence of the Balkot collective. Balkot collective decided to leave Riotic in 2004 because they felt that the Riotic activities had become very commercial, especially with the establishment of a commercial event organization called Berandalan Bandung.

The number of distros and clothing companies in Bandung reached about 500 in 2010, although that number has now dropped dramatically to around twenty. Some distros maintain the relationship of visual communication and political work connected with the punk scene, although usually in the form of temporary stalls that only appear at shows. The intimate connections between punk hangouts, lapak stalls and distros points to the centrality of commodities in punk communities, as well as highlighting the commercial (indeed, neo-liberal) tendencies inherent in that relationship. The rapid expansion and decline of punk-inspired distros also lays bare the weakness of commercially focused punk, both ideologically and in terms of sustaining punk communities.

\section{PUNK MUSIC COMMODITIES}

One of the most significant effects of punk was its democratization of sections of the music and culture industry, with the rise of independent record labels and a wider 'DIY culture' (Laing 1985: 118-19). In Indonesia, the 'indie scene', based on small local record labels, clothing design companies, and media, largely developed out of the institutions and practices put in place by the underground (Luvaas 2009). At the same time, more resolutely DIY practices of production have continued to play an important role in underground music scenes, and especially in punk. Punk's underground critique extends to the commodification of the underground itself, and intensifies the underground commitment to autonomous production, offering a constrained escape route without actually overcoming the dialectical oppositions between underground and mainstream, resistance and domination, or labour and capital. Despite the constraints of aestheticized resistance, they strive to make their production and consumption of cultural products matter in a social and political sense. To the extent that their punk self-marginalization takes the form of a performance of exclusion and precariousness, it may also reassert rather than undermine the dominant hierarchies of class privilege.

Underground music establishes a playful habitus for identity experimentation and contestation (Baulch 2007). Live performance is at the heart of the scene, but the punk community is sustained on a daily basis by the production and exchange of media products, and particularly recorded music in the form of cassettes, CDs and digital music files. Riotic Records released its first album, by the band Hellburger (1991-95), in 1996. However, its role as a punk music label started in 1997 when it released a compilation album consisting of seventeen punk bands in Bandung titled Bandung Burning - Bandung Punk Rock Storm Vol. 1 and an album by a punk band named Runtah. In the same year, another record label, 40.1.24, also released a compilation album titled Masaindahbangesekalipisan consisting of fifteen bands - not all of the bands included on this were punk, but they were bands that had grown together in Saparua. In 1997, another compilation titled Bandung Holocaust was released by Holocaust Records. Bandung's international reputation as a city with a growing punk and DIY scene started when Injak Balik! A Bandung Punk/HC Comp. was released by the Tian An Men $89^{4}$ label in France, on vinyl with a
4. Tian An Men 89 Records, established in 1993, specializes in releasing punk music (on vinyl) by bands from parts of the world where doing so is made difficult, whether because of financial reasons, civil wars or lack of record factories. They use resolutely DIY distribution networks and are not-for-profit. For more on the Injak Balik! compilation see http://tam8grecords. com/records2.html, accessed 16 May 2017 . 

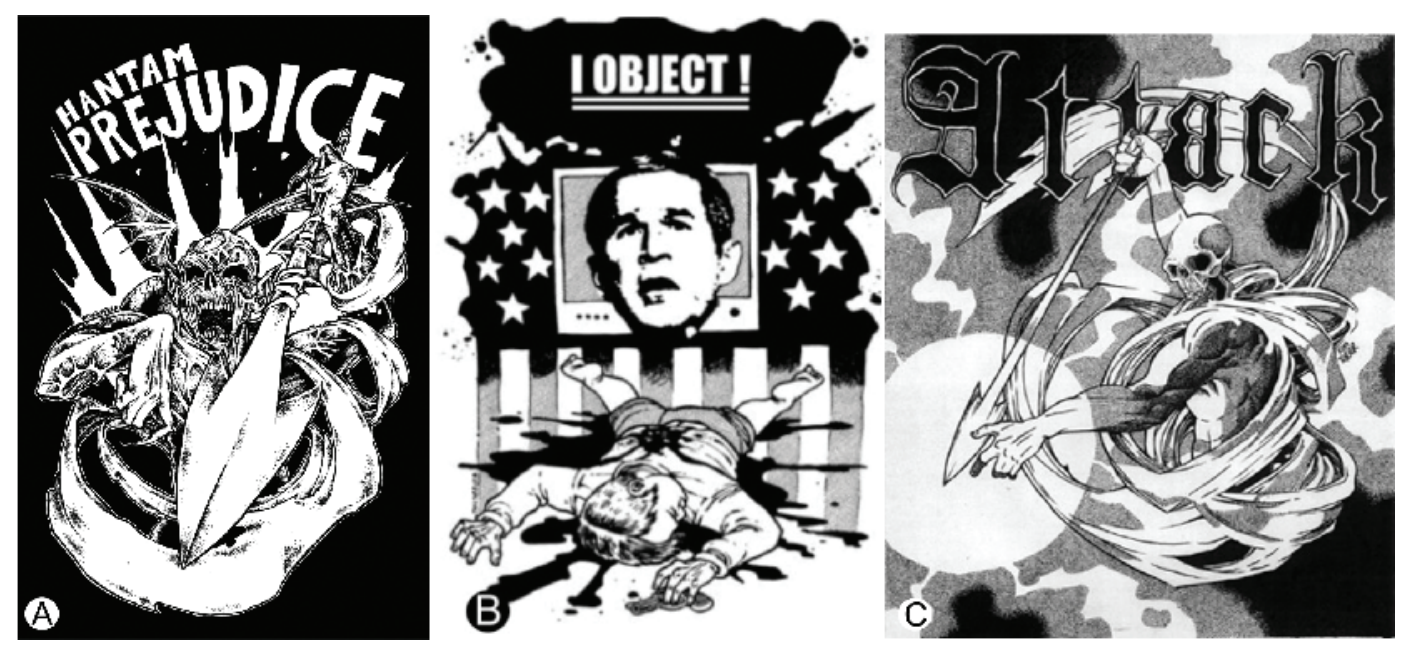

Figure 7: KenTerror artwork: (A) Cover Album Hantam Prejudise Compilation - Indonesia 2003; (B) Cover Album I.Object - USA 2006; (C) Cover Attack zines - Sweden 2001. Artwork and permision by KenTerror (C) 2001-2006.

run of 500 copies. This was the first punk album compilation from Indonesia to be released on vinyl by an overseas music label. Another compilation, titled Hantam Prejudice (Figure 7) consisting of 24 bands, was released in 2003 by Pin Rose Records, with cover artwork by Ken Terror - marking the beginning of a relationship between punk and art. Ken Terror elaborated his punk identity and everyday issues (social, politics and economy), and transformed these subjectivities through his own imagination into the art of illustration (Prasetyo 2012). The confrontational approach adopted by Ken Terror and other radical Indonesian artists brought them into an alliance with the developing punk movement in Indonesia (Prasetyo 2012). Indeed, most of the artists who were involved in this'street art' faction were punk artists. Political commitment also informs essentially aesthetic performances, lending them intensity and meaning, and can itself take on an aesthetic character. Punk's aesthetic of resistance can be seen in artwork production, and in Bandung illustrator artists such as Ken Terror have emerged from the global punk scene especially in Bandung, designing album covers for numerous bands, along with merchandise, flyers for DIY collective events (gigs) and zines.

After the release of Bandung Burning 1 (1997) and the Injak Balik compilation (1997) (Figure 8A), the development of the punk scene in Bandung became more rapid, as identified by the appearance of new punk collectives and the release of compilation albums involving numerous punk bands representing punk cells in Bandung (such as Bandung Burning II (2010) and Punx and Rawk (2011) (Figure 8B). The Balkot collective also created a music compilation entitled Balkot Terror Project (2010) which consisted of twenty bands (Figure 8C) and the Riung Mumpulung compilation (2012) with 21 bands. The release of so many punk compilation albums indicates that the Bandung punk scene is big, yet fragmented, so their collective power as a social or political movement remains weak.

Punk production can be considered in terms of creative labour, a form of labour which remains somewhat problematic for the capitalist economy even 


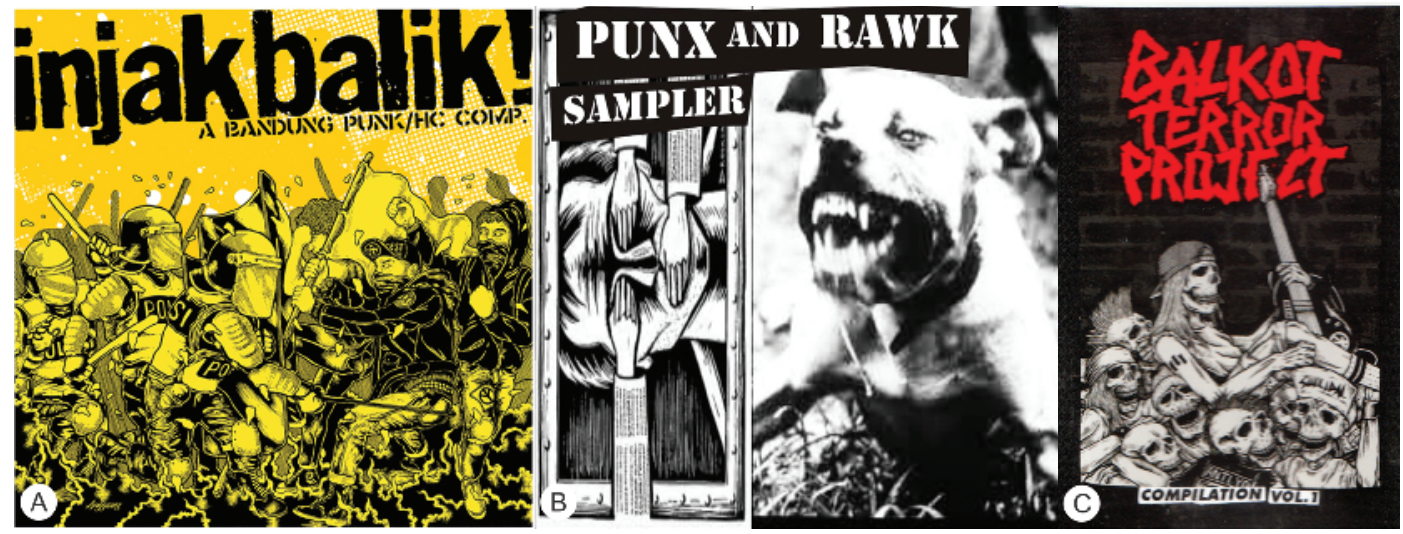

Figure 8: (A) Injak Balik! A Bandung Punk/HC Compilation, Tian An Men 89 record (France) - 1997; (B) Punx and Rawk, Rocket27 record (Bandung) - 2011; (C) Balkot Teror Project Compilation, Balkot record (Bandung) - 2010. For A and B based on various sources, under creative commons attribution licence - 2016 and C by Frans Ari Prasetyo (C) 2010.

as it is increasingly incorporated within it. Artistic creativity represents freedom from alienated work, but within the cultural industries this creativity is itself transformed into a form of labour that produces alienated commodities. The basis for the commodification of cultural production is the alienation of cultural labour, but this process is itself fraught with contested values. Some argue that cultural production is based on autonomous forms of sociality and creativity that fundamentally resist incorporation into capitalist circuits of value. This relative autonomy is often modelled on the heroic independence of the bohemian artist (Ross 2000) or the energetic entrepreneurialism of youth culture scenesters (McRobbie 2002). Like many other cultural artefacts, punk products remain associated in significant ways with those who have produced them, even as they circulate through exchange networks with or without money. Those who lay claim to anti-commercial authenticity can be considered to be part of the underground pursuit of subcultural capital; the aesthetic value of cultural artefacts is often based on the denial of their economic value as exchangeable commodities. As evidence of punk artefacts functioning as commodities, a record collection can serve as a marker of distinction, based on the display of the collector's exclusive subcultural knowledge as well as the rarity and expense of the records themselves. Record collecting is often viewed as a hypocritical form of identification with punk, 'an antithetical and alienated form of luxury consumption' masquerading as fidelity to punk history (Bywater 2009). However in Bandung several punk albums or punk compilation albums like Injak balik and Bandung Burning have become rare and expensive collector's items. In modern consumer culture, the role of commodities as material objects has been displaced by the commodity image (Baudrillard 1996; Debord 1977).

\section{ZINES}

The development of punk in Bandung relied on communication, the distribution of knowledge and information, and opinion making - processes which require media. Punk communities did not want to follow the mainstream 
and corporate media so they created their own; DIY zines being a cheaply produced and easily distributed alternative. Some zines were influential amongst underground communities, providing rich information about western and local music, culture, politics, history, philosophy, health tips and underground movements. Zines have been pivotal in building social and political consciousness amongst underground youth since the 1990s, and as Duncombe (1997) argues zines have played an important role in the personalization of politics within DIY and anarchist-punk culture. Punkers in Bandung produced zines covering music issues and politics, becoming an open space to address issues that could not be covered in the mainstream media. Punk communities used photocopy machines in their low budget productions, enabled by the popularity of photocopy businesses in many areas around universities in Bandung. Media such as leaflets and newsletters had been popular in Bandung and were usually produced and read by specific groups, such as religious groups, or distributed at demonstrations. The popularity of photocopy services emerged in the same period as the growth of the punk scene in the 1990s. While most zines in Bandung were originally printed from a computer or typewritten, others were cut-and-pasted or hand-written. The messy aesthetic of zines serves as a marker of authenticity - zines should look as if they are amateur and idiosyncratic, the antithesis of 'slick' commercial design. Zines are often highly personal individual projects, the products of one person's initiative, but they are also produced in the context of, and contribute to, a wider community of communication (Duncombe 1997; Moore 2007).

Riotic was the first community in Bandung to produce a zine, called SubmissiveRiot, published for the first time in 1997 (Figure 9A) by Pam, Linggo and Behom. They felt challenged to create a better zine than the one they got from their friends in Australia and Singapore. However, more importantly, they wanted to distribute information about the punk scene and to use it as media to publish political ideas (Luvaas 2012). SubmissiveRiot was only printed in a run of 30-40 photocopies, as a four to eight page A5 booklet, priced at 500 IDR. Pickles (2001) describes how SubmissiveRiot redefined punk as political struggle, calling for a boycott in 1998 of a punk event that was deemed to be a capitalistic enterprize writing that '[r]eal punks wouldn't spent a cent to support this enterprise' (quoted in Pickles 2001: 58).

SubmissiveRiot published thirteen editions over the course of about one year, with each edition consisting of only one or two A4 sheets. Due to internal frictions in Riotic (described above) the distro decided to no longer to be a political base of punk and ceased publishing the zine. In the months after the publication of Submissive Riot (Pam, Linggo and Behom 1997), Kontaminasi Propaganda (Pam, Linggo and Ucok 1998) was also published (Figure 9B). Linggo (vocalist of Total Riot and National Scandal) and Pam (vocalist of Kontaminasi Kapitalis) were the people behind this zine, yet they produced it outside the Riotic rubric. This zine later became associated with anarchistpunk, representing punk ideas in the political literacy movement. In the midst of the political upheavals of 1998, the punkers in Riotic who developed Front Anti-Fasis also produced a zine named Militansi (Figure 9). Unfortunately, both Kontaminasi Propaganda and Militansi were only published once each.

In the Reformasi period the number of zines grew as the political landscape in Indonesia became more open. During this period, the zine found political form more widely among punkers. The end of the militarist regime and the economic crisis opened up new space for critical ideas about change in society. This came at the same time as the development of punk culture 

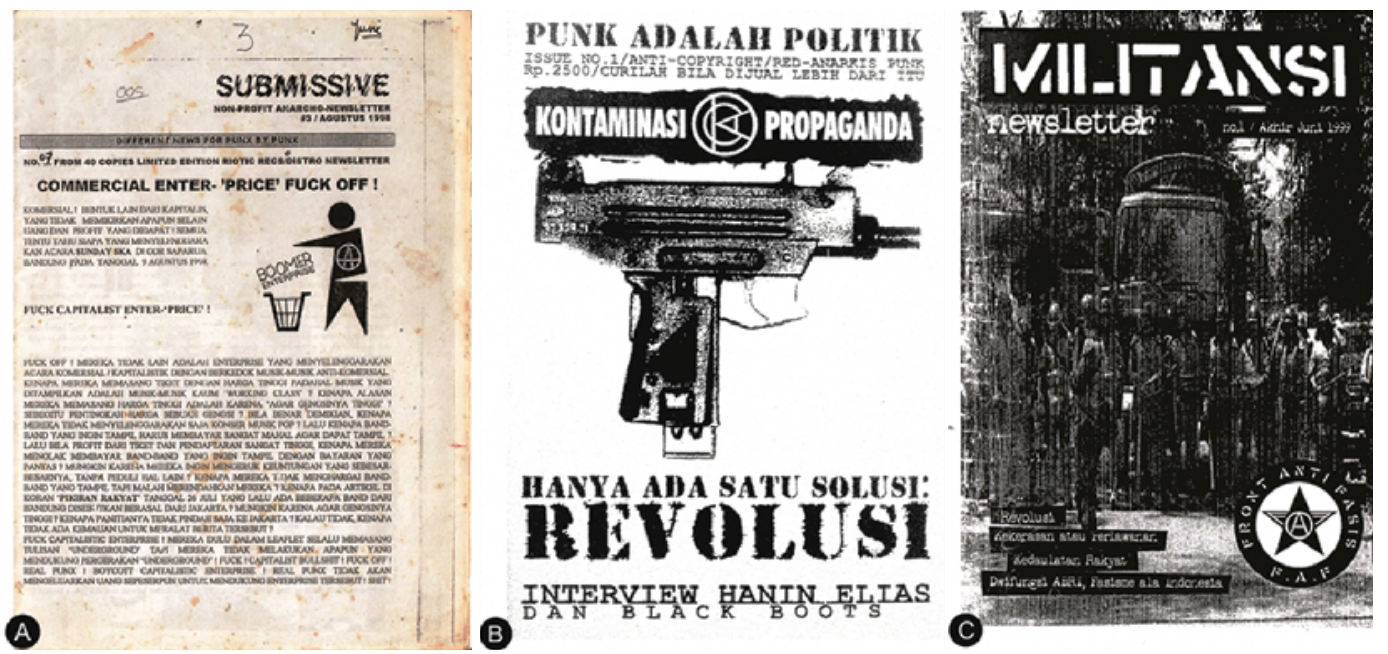

Figure 9: (A) Submissive Zine No. 3 - 1998 published by Riotic; (B) Kontaminasi Propaganda Zine, published by Kontaminasi Kapitalis - 1998; (C) Militansi Zine No. - 1999, published by Front Anti Fasis (FAF) Bandung. Collections and owner zine by Frans Ari Prasetyo (C) 1998-1999 and permission from the zine maker.

in Indonesia, which was positioned as part of a resistance culture. Zines that were published between 1998 and 2000 included Tigabelas, Membakar batas and PuncakMuak. Tigabelas zine (Figure 10A) was published in 1998 by Arian13, the vocalist of the iconic punk/HC band Puppen. The content and design of Tigabelas was taken seriously (60 pages, A5) and production was aided by Ucok, from Homicide (a political hip hop group, also associated with FAF). Ucok also created a personal/political zine named Lyssa Belum Tidur, which was published in five editions from 1998 to 2005. The Balkot Collective was highly productive in zine publishing as well, including, among others, $x$ Lapukx Zine consisting of five editions, published in 2004, 2005, 2006, 2009 and 2016. Other zines created by members of bands associated with the Balkot collective include Beyond the Barbed Wire 1 (2005) created by Tremor (Figure 10B) (with a second and third edition of this zine published in 2006 and 2007) and Hardcore Heroes vs. Punk Partisans (2005) (Figure 10C) created by Cahyo who was the guitarist of XmanusiaBuatanX (this zine was published twice more, in 2006 and 2007).

The popularity of zines in Bandung has also been marked by the Bandung Zine Fest (BZF), the first of its type in Indonesia, held in 2012, 2013 and 2016. The festivals were managed by individuals who had been members of Balkot, though BZF 3 (2016) turned to become more commercial and was organized in a building owned by the military, in a similar pattern to the period when punk shows also moved to become commercial and were held in military areas, and producing similar friction and fragmentation within the Balkot collective. At BZF 3, the zines involved in the festival were not only those of political and visually modest zines, but also zines that publish popular issues with more colourful designs. The latest development of zines indicates that they do not only serve as an alternative media of punk communities but have also become a popular alternative media with a broader young audience with an interest in literary and visual cultures. This is yet another example of punk's impact 

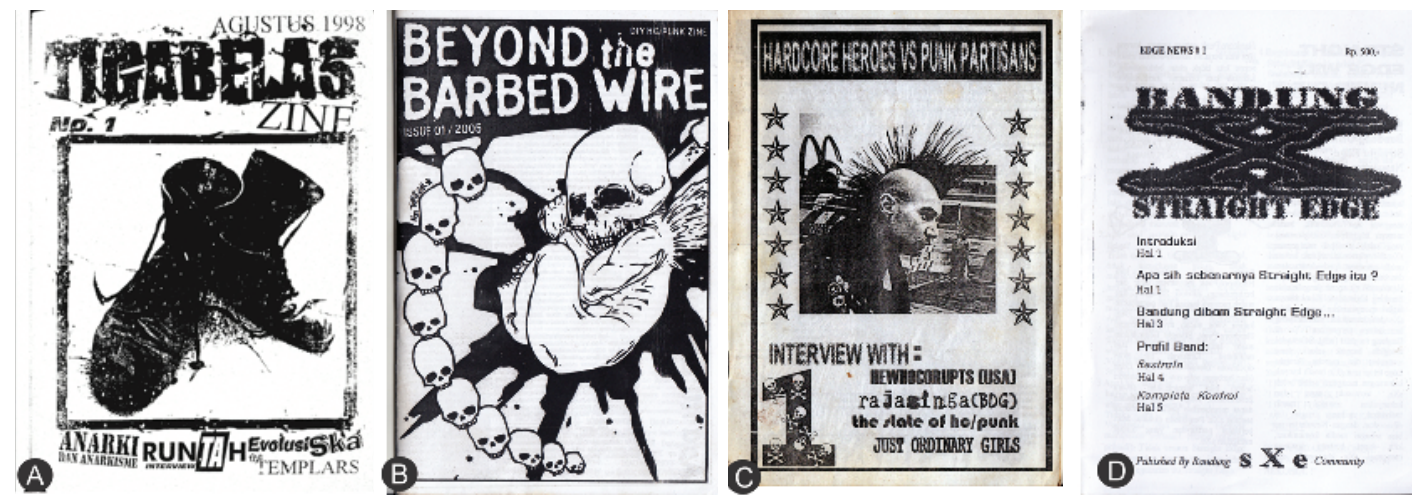

Figure 10: (A) Tiga Belas Zine No. 1 - 1998, personal published by Arian13; (B) Beyond The Barbed Wire No. 1 - 2005, personal published by Tremor-Balkot Collective; (C) Hardcore Heroes vs. Punk Partisans Zine No. 1 - 2005, personal published by Cahyo-Balkot Collective; (D) Bandung X Straight Edge (S X E) - 200405, personal published by Balkot Collective. Collections zine by Frans Ari Prasetyo 1998-2005, with copyright and permission from the zine maker.

on the wider culture of Bandung - though, of course, this relationship runs in both directions, and it has been the particular context of Bandung city that has laid the basis for the development of the punk scene there.

\section{CONCLUSION}

The underground music scene in Bandung is part of a creative culture which includes political and youth movements. While this does not reflect the much more fluid use of scene and community in practice, it does mark a significant disjuncture in terms of social organization, production practices and values. Because the music scene cannot represent urban political movement, this is only part of the youth culture. As with other forms of punk and underground music, music and fashion are closely linked as mutually reinforcing aspects of subcultural style. The political discourse around punk is moving further and further from the 'original' perspective of punk as an idiom of resistance youth culture, to form a subculture itself, entrenched in a new vision of global relevance narrated in local punk contexts, in which daily activities include political activity. In Bandung, punk became one of the bases for the production of youth culture and marginal community resistance against the militarist and fascist New Order. Punk gives another historical narrative of the development of urban communities in Bandung, through the economic and political spaces of youth culture - punk appropriates daily resistance to the system and gives it aesthetic form. Punk collectives in Bandung have an historical legacy of youth culture activities, cultural production, political statement, and DIY ethics, which, in a contested fashion, survives autonomously against globalization, capitalism and the regime.

The objectified value that punks ascribe to records, zines, and other material artefacts works against the abstracting logic of commodification. DIY is grounded in an independent network of production, which operates to a significant extent outside the commercial organization of the cultural industries. In the Indonesian underground scene, and especially in punk, 
many people argue that piracy of mass media products serves as a form of resistance to the domination of the corporate cultural industries as well as a way of responding to their subordinate and marginal position in the global economy. The DIY value of autonomy builds on the punk ethic of independent living and self-expression which O'Hara (1999) calls 'the philosophy of punk'. The youth in the Bandung underground music scene have been implementing this DIY ethos by developing commercially 'independent' media and various forms of cultural production. Punk contributes to the historicity and process of disalienation and political engagement, with the production of DIY culture via underground merchandise, record labels and self-published zines.

The Bandung punk scene is a rather small and marginal community, but its participants are engaged in a project of autonomous cultural production that reveals political possibilities, desires, and contradictions of much wider significance. Their values of autonomy and community are both specific to their own praxis and gesture towards a more inclusive project of social transformation. The cultural politics of punk can thus be understood as a politics of identity, representation or recognition, and politics of value. Punk is an attempt to move beyond spectacular subcultural resistance, to express and realize alternative social values, community empowerment, production of space and scene, including artefacts and material culture in the city. By tracing key aspects of the trajectory of punk's development in Bandung it is possible to identify a critical historical narrative for Bandung as a whole and because of punk's combination of global spread and local specificity, this critical punk historiography is likely to be fruitful in a wide range of contexts worldwide.

\section{ACKNOWLEDGEMENTS}

The author is very grateful to Acep Muslim for discussion of this article, and to Jim Donaghey for some substantial editing and his kindness in reviewing this article.

\section{REFERENCES}

Appadurai, A. (ed.) (1986), 'Introduction: Commodities and the politics of value', in The Social Life of Things, Cambridge and New York: Cambridge University Press, pp. 3-63.

Baudrillard, J. (1996), The System of Objects, London and New York: Verso.

Baulch, E. (2007), Making Scenes: Reggae, Punk, and Death Metal in 1990s Bali, Durham and London: Duke University Press.

Bourdieu, P. (1984), Distinction: A Social Critique of the Judgement of Taste, Cambridge, MA: Harvard University Press.

Bywater, J. (2009), 'Archive trouble: Collecting and British punk', http:// www.metamute.org/editorial/mute-music/archive-trouble-collecting-andbritish-punk. Accessed 18 May 2017.

Clark, D. (2003), 'The death and life of punk, the last subculture', in D. Muggleton and R. Weinzierl (eds), The Post-Subcultures Reader, Oxford: Berg, pp. 223-36.

Clarke, J., Hall, S., Jefferson, T. and Roberts, B. (1976), 'Subcultures, cultures and class: A theoretical overview', in S. Hall and T. Jefferson (eds), Resistance Through Rituals: Youth Subcultures in Post-War Britain, London: Hutchinson, pp. 9-74. 
Connor, L. and Vickers, A. (2003), 'Crisis, citizenship, and cosmopolitanism: Living in a local and global risk society in Bali', Indonesia Journal, 75, pp. 153-80.

Debord, G. (1977), Society of the Spectacle, Detroit, MI: Black and Red.

Duncombe, S. (1997), Notes From Underground: Zines and the Politics of Alternative Culture, London and New York: Verso.

Dunn, K. (2016), Global Punk: Resistance and Rebellion in Everyday Life, London: Bloomsbury Academic.

Featherstone, M. (1991), Consumer Culture and Postmodernism, London: Sage.

- (1995), Undoing Culture: Globalization, Postmodernism and Identity, London: Sage.

Florida, R. (2004), The Rise of the Creative Class, New York: Basic Books.

Friedman, J. (1990), 'Being in the world: Globalization and localization', in M. Featherstone (ed.), Global Culture: Nationalism, Globalization and Modernity, London: Sage, pp. 311-28.

Hall, S. and Jefferson, T. (eds) (1976), 'Resistance through Rituals', in Resistance Through Rituals: Youth Subcultures in Post-War Britain, London: Hutchinson, pp. 9-74.

Harvey, D. (2002), 'The art of rent: Globalization, monopoly and the commodification of culture', Socialist Register Journal, 38, pp. 93-110.

Hebdige, D. (1979), Subculture: The Meaning of Style, London: Routledge.

Heryanto, A. (1999), 'The years of living luxuriously: Identity politics of Indonesia's new rich', in M. Pinches (ed.), Culture and Privilege in Capitalist Asia, London and New York: Routledge, pp. 159-87.

Iskandar, G. H. (2006), 'Fuck you! We're from Bandung! - MK III', http:// hetero-logia.blogspot.co.id/search?q=fuck . Accessed 6 July 2017.

Kusno, A. (2000), Behind the Postcolonial: Architecture, Urban Space and Political Cultures in Indonesia, London and New York: Routledge.

Laing, D. (1985), One Chord Wonders: Power and Meaning in Punk Rock, Milton Keynes: Open University Press.

Luvaas, B. (2009), 'The Indie takeover: Independent record labels give the majors a run for their money', http://www.insideindonesia.org/theindie-takeover?highlight=WyJsdXZh $\overline{Y X M i X Q \% 3 D \% 3 D . ~ A c c e s s e d ~} 18$ May 2017.

- (2012), DIY Style: Fashion, Music and Global Digital Cultures, London and New York: Berg.

Ma, E. (2002), 'Translocal spatiality', International Journal of Cultural Studies, 5:2, pp. 131-52.

Martin-Iverson, S. (2011), 'The politics of cultural production in the DIY hardcore scene in Bandung, Indonesia', Perth: University of Western Australia.

- (2012), 'Autonomous youth? Independence and precariousness in the Indonesian Underground music scene', The Asia Pacific Journal of Anthropology, 13:4, pp. 382-97.

(2014), 'Bandung Lautan hardcore: Territorialisation and deterritorialisation in an Indonesian hardcore punk scene', Inter-Asia Cultural Studies Journal, 15:4, pp. 532-52.

McRobbie, A. (ed.) (1988), 'Second-hand dresses and the role of the ragmarket', in Zoot Suits and Second-Hand Dresses, Boston, MA: Unwin Hyman, pp. 23-49.

- (2002), 'Clubs to companies: Notes on the decline of political culture in speeded up creative worlds', Cultural Studies Journal, 16:4, pp. 516-31. 
Moore, R. (2005), 'Alternative to what? Subcultural capital and the commercialization of a music scene', Deviant Behavior Journal, 26:3, pp. 229-52.

_ (2007), 'Friends don't let friends listen to corporate rock: Punk as a field of cultural production', Journal of Contemporary Ethnography, 36:4, pp. 438-74.

O'Connor, A. (2004), 'Punk and globalization: Spain and Mexico', International Journal of Cultural Studies, 7:2, pp. 175-95.

O'Hara, C. (1999), The Philosophy of Punk: More Than Noise!, Edinburgh and San Francisco, CA: AK Press.

Peck, J. (2009), 'The creativity fix', Variant Journal, 34, pp. 5-9.

Pickles, J. (2001), 'Of purple hair and protest: Beyond spectacular style, Bandung's punks in collective action', Honors thesis, Canberra: Australian National University.

_ (2007), 'Punk, pop and protest: The birth and decline of political punk in Bandung', RIMA Journal, 41:2, pp. 223-46.

Prasetyo, F.A. (2012), 'Indonesian Illustration open the world: Challenge for underground (punk) illustrator of Indonesia', ArtePolis Conference \#4, Bandung, Indonesia, 5-6 July, ITB: Bandung, pp. 383-92.

Robison, R. and Hadiz, V. R. (2004), Reorganising Power in Indonesia: The Politics of Oligarchy in an Age of Market, London: Routledge Curzon.

Ross, A. (2000), 'The mental labour problem', Social Text Journal, 18:2, pp. 1-31.

Sen, K. and Hill, D.T. (2000), Media, Culture and Politics in Indonesia, Melbourne: Oxford University Press.

Soemardi, A. R. and Radjawali, I. (2004), 'Creative culture and urban planning: The Bandung experience', 11th Conference of the International Planning History Society, International Society of Planning History, Spain: Barcelona, 14-17 July.

Wallach, J. (2008), 'Living the punk lifestyle in Jakarta', Ethnomusicology Journal, 52:1, pp. 98-116.

Weintraub, A. N. (2006), 'Dangdut soul: Who are "the People" in Indonesian popular music?', Asian Journal of Communication, 16:4, pp. 411-31.

\section{SUGGESTED CITATION}

Prasetyo, F. A. (2017), 'Punk and the city: A history of punk in Bandung', Punk $\mathcal{E}$ Post-Punk, 6:2, pp. 189-211, doi: 10.1386/punk.6.2.189_1

\section{CONTRIBUTOR DETAILS}

Frans Ari Prasetyo works as an independent researcher with an interest in ethnography and the evolution of the socio-political implications of arts, visual, urban culture, and sub-cultures such as punks, artists, underground activists, indigenous people, towards citizen participation and social change. Find his works at http://orcid.org/0000-0003-0556-8546.

E-mail: fransariprasetyo@gmail.com

Frans Ari Prasetyo has asserted his right under the Copyright, Designs and Patents Act, 1988, to be identified as the author of this work in the format that was submitted to Intellect Ltd. 


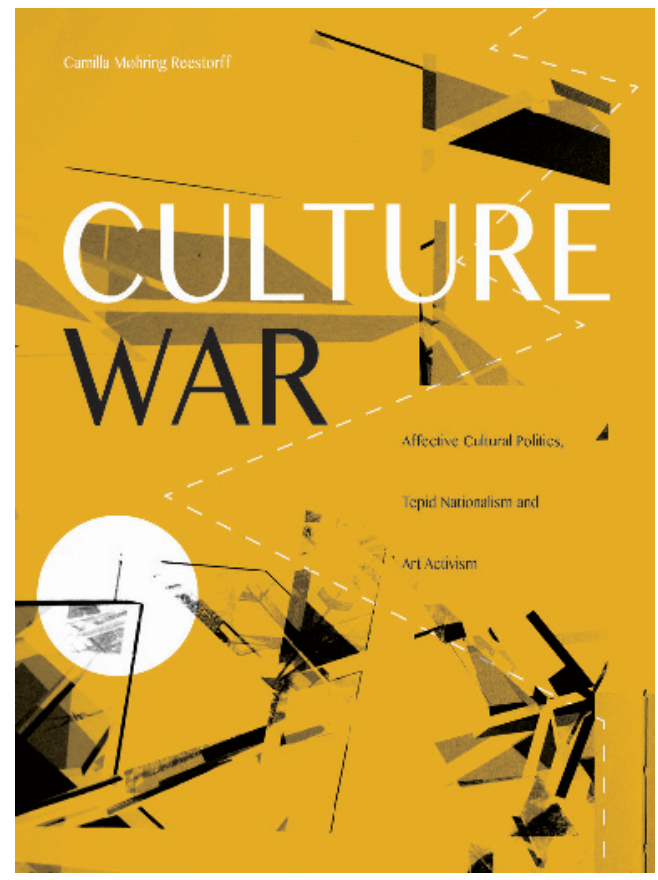

\section{Culture War}

\section{Affective Cultural Politics, Tepid Nationalism and Art Activism By Camilla Møhring Reestorff}

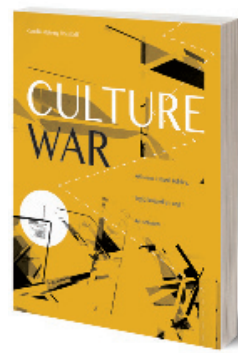

ISBN 978-1-78320-758-9 $327 \mathrm{pp} \mid £ 38.50, \$ 51.50$ Paperback | $170 \times 230 \mathrm{~mm}$ Published Spring 2017
The culture wars have sparked prominent political debates for many years, but particularly in Europe and America since 2001. Focusing specifically on Denmark, Culture War aims to analyse and understand the rise of right-wing nationalism in Europe as part of the globalization and mediatization of the modern nation state and the culture war and politics arising from it.

Employing a detailed and critically reflective argument covering social media, television, political campaigns, advertising and 'artivism', Camilla Møhring Reestorff refuses the traditional distinction between the world of visual culture and the political domain, and she provides multiple tools for understanding the dynamics of contemporary affective cultural politics in a highly mediatized environment. 